\title{
Identifying Tourist Places of Interest Based on Digital Imprints: Towards a Sustainable Smart City
}

\author{
Luis Encalada $^{1}$ (D), Inês Boavida-Portugal ${ }^{2}$, Carlos Cardoso Ferreira ${ }^{1}$ (D) and Jorge Rocha ${ }^{1, *}$ \\ 1 Institute of Geography and Spatial Planning, Universidade de Lisboa, Rua Branca Edmée Marques, \\ 1600-276 Lisboa, Portugal; luisencalada@campus.ul.pt (L.E.); carlosferreira@campus.ul.pt (C.C.F.) \\ 2 Department of Spatial Planning and Environment, University of Groningen (RUG) P.O. Box 800, \\ 9700 AV Groningen, The Netherlands; i.boavida.portugal@rug.nl \\ * Correspondence: jorge.rocha@campus.ul.pt; Tel.: +351-210-442-950
}

Received: 31 October 2017; Accepted: 9 December 2017; Published: 13 December 2017

\begin{abstract}
As cities become increasingly complex, Information and Communication Technologies (ICTs) bring smartness into organisations and communities, contributing to a more competitive tourism destination, i.e., smart tourism destinations. Enhanced information access coupled with a new kind of tourists avid for online content and predisposed to share information on social media, allows for a better understanding of tourist behaviour regarding their spatial distribution in urban destinations. Thus, smart tourism portrays individuals as information makers, refining the available alternatives for tracking their location. Big data analytics is a technology with the potential to develop Smart City services. From the analysis of the spatial distribution of tourists in the city of Lisbon based on data collected from the 'Panoramio' social network, we identify the most popular places in the city in a context of tourist visits. This new data largely contributes to understanding the consumption of space within urban tourist destinations and therefore enables us to differentiate the overcrowded places from the ones with potential to grow. This allows decision-makers to imagine new ways of planning and managing towards a sustainable 'smart' future.
\end{abstract}

Keywords: smart city; smart tourism; big data; sustainability; social networks; geotagged photos

\section{Introduction}

\subsection{ICTs and Big Data Analytics for Rising Smartness on City Tourism Destinations}

According to the United Nations, by the year 2050 almost $66 \%$ of the world's population will be living in cities [1]. This urban pressure will raise a variety of problems and important challenges that will likely question the economic, social, and environmental sustainability of cities [2,3].

In parallel with this inexorable and widespread population concentration in urban centres, cities are also the object of growing tourism production and consumption, capturing ever-increasing flows of visitors, according to several authors [4], as well as recent reports and insights (e.g., Global Destination Cities Index [5]; Euromonitor International [6]).

Tourism is not only a mobility pattern in the cities and thus a geographical feature in itself, but it is also "... assuming a growing political and cultural importance indirectly in relation to the ranking of world cities as places to live, work and do business" [7]. As UNWTO claims, on a wider perspective, tourism is becoming " ... a very important element in all policies related to urban development $(\ldots)$ not just a strategy to provide a competitive product to meet visitors' expectations but a way to develop the city itself and provide more and better infrastructures and bring conditions to residents" [8].

With more than half of the world's population living in cities, infrastructure will face increasing pressure [9]. In particular, non-digital and non-automated infrastructures of the city are already dealing with several technical and physical problems [10]. Nowadays, the performance of cities depends 
not only on their physical infrastructure, but also on accessibility and the quality of knowledge communication and social networks [11].

Smart cities have been presented as a panacea to urbanization driven problems and a way to achieve sustainable development [12]. Information and Communication Technologies (ICTs) are in the core of this discourse [13], which underlines the enhancement of cities' performance in many fields [14].

Supporters of the smart cities paradigm stress the potential for stimulating ecological integrity and social equity towards the greater aim of urban sustainability [15]. Opponents argue that slight attention is given to the social aspects of sustainable development and to the basic social dimension of the city [16]. So far, smart cities enthusiasts have succeeded in hiding answers to the big issues (e.g., sustainability) rather than providing information [17]. Still, smart cities are a strategic vision to stretch for sustainable futures, rather than a depiction of the current reality [18].

As cities become increasingly complex systems, ICTs intertwine all activities and services, fostering more connected, informed, and involved citizens. ICTs make cities more accessible and pleasant for both residents and visitors, and help cities to manage the challenges that keep emerging $[19,20]$.

ICTs have also brought several new tools to the tourism industry. Nowadays, tourism is facing a new set of challenges resulting from modifications in tourism consumers' behaviour by influence of the emerging ICTs and by the generalisation of their use as well [21]. From the standpoint of tourism, ICTs can potentially contribute by generating added-value experiences for tourists, while refining efficiency and supporting automated processes [22].

The smart city paradigm perfectly embraces ICTs as it is characterised by an environment where technology is rooted in the city [23] and facilitates access to enhanced services for city visitors (both residents and tourists), such as access to real-time information. Smart cities include different areas of the city administration. For example, the concept of smart tourism destination arise from the development of smart cities [24], i.e., the blossoming of the smart city also encourages the emergence of smart tourism.

The World Tourism Organization (UNWTO) introduced the smart tourism concept [25] and defined it as clean, green, ethical, and quality tourism, among other characteristics. Thus, smart tourism should be capable of meeting the requirements of both short-term economic needs and long-term sustainable development. Since tourism is a complex activity, smartness applied to tourism should encompass both the availability of services and the efficiency of the city as a whole. Smart tourism destinations can be perceived as places utilizing the ICTs to co-create value, pleasure, and experiences for the tourist and profit for the destination administration [24].

From a technological point of view, smart city and smart tourism are two strongly linked notions [19]. Smart tourism refers to the use of technology, attributing more importance to the number and/or the quality of tourism-related apps available in the city, while the tourism smartness paradigm has to account for the temporary dimension of tourism practiced by non-residents $[19,26]$.

Yet, the integration of ICTs per se within a tourism destination is not enough for a city to become a smart tourism destination. There is a need for enhancing human capital and other forms of skill development among the citizenry [3]. Destination managers have to understand the multifaceted genesis of smartness in order to enhance competitiveness [27].

When it comes to creating sustainable smart cities, it is imperious to understand what makes a city tick and what makes people want to go there. Therefore, becoming smart implies reinforcing a city's uniqueness rather than allowing it to become impersonal and homogenized. ICTs must increase efficiency but at the same time improve the liveability of the city, promoting engagement with the city and respect for the environment and the several nuances of a city's cultural identity, i.e., what makes it different from other cities.

Bakhtin [28] coins three terms to analyse the clash between tourists, residents and local cultures, namely heteroglossia, polyphony and carnivalesque. The first one focuses on understanding tourism and its impact on local cultures. The second term stresses the ubiquitous and mediating mission of 
the tourism authorities, i.e., operators, tourists, and local residents contribute to creating the profile of each destination, but the authorities have the responsibility of defining the overall strategy to enhance marketability [29]. Finally, the third term accounts for the multiplicity of situations beyond the control of the authorities. The way that attractions selection become hot (or cold) on social media informs the choices that authorities have to make in their strategies.

Furthermore, the active role of the anthropic system, i.e., the human factor represented by city users-both residents and tourists—-has been gradually gaining importance as it bears direct implications on the way cities become smart.

In fact, as stated by some authors $[26,27,30]$, it is the interconnectivity between heterogeneous human actors and the digital ecosystem-more precisely, the co-created value collaboratively shaped by this socio-technical synergy - that contributes to introducing smartness in cities. Hence, tourism can be a privileged field to test actual accomplishment of the potentials made available by the smart city paradigm $[25,31]$.

The smart city paradigm and consequently the smart tourism approach have to address both tourists' behaviour and consumption. These should be sustainable and restrained, preventing the urban system from exceeding its carrying capacity threshold and degenerating into an entropic region [31].

Some, although not all, of the smart environment features foster improved quality of life, governance, resilience and principally an intelligent managing of city facilities and natural resources, and thus sustainability [32].

\subsection{Research Framework}

Smart Tourism Destination initiatives rely on the combination of hard and soft smartness components [27]. While the former stress recent developments in ICTs and the Internet of Things (IoT), both have empowered the gathering and analysis of a huge amount of information (referred to as big data), providing real-time insights on human behaviour [33]. Only in association with the anthropic system can big data provide value for a competitive advantage of tourism destinations.

Hence, the deployment of ICTs has become a fundamental infrastructure that contributes to competitiveness. The latest developments in Social Network platforms and the IoT are producing new impacts on tourism destinations and, particularly, supporting information exchange regarding tourism activities [34,35].

One of the great challenges of smart cities is the mining of relevant information from the ICTs infrastructure of cities. Such extraction usually relies on the use of sensors that require high public investment [36]. To overcome such a difficulty, some studies suggest using social media to identify the perception of residents and visitors about a particular city [11,19,27].

Big data analytics has emerged as a technology with the potential to augment smart city services [32,37]. Big data is characterised by a huge volume and variety of data types; created at continually increasing rates [38]. Big data analytics allows for the extraction of meaningful information from large amounts of data produced by ICTs [37-39].

Big data provides insights from diverse sources of data. The features derived from social media are typically unstructured when compared with big data collected in other contexts [40].

The better access to information facilitated by ICTs and a new profile of tourists seeking and sharing online content have contributed to an improved knowledge of the characteristics and behaviour of tourists [41,42]. In this context, individuals themselves have become generators of information, contributing to boost the available alternatives for tracking their location [43].

User-generated data retrieved from social media include, among others, geotagged photos. Contrasting traditional survey-based methods, this data can offer cost-effective information on activities and preferences of tourists [44]. Social media has become gradually more important in many aspects of tourism, particularly in information search, decision-making behaviours, tourism promotion and in focusing on best practices for interacting with consumers [45]. 
All this innovation generated by ICTs in terms of information and information sources has emerged as an additional and complementary support tool for the more formal/traditional sources of data collection in tourism, particularly in local contexts (e.g., urban destinations) where there are still various constraints on the availability and appropriateness of information [7].

Moreover, it could also suppress restrictions that came from problems like sample size, nonresponse bias, self-reported errors and time and location constrains [46]. Nonetheless, there are still some concerns regarding the use of social media content in this context [47]. These are mainly related to data quality [33], to the posts potential location inaccuracy, to the representativeness of the population using social media [48] and to the possible biased behaviour on social media [49].

When tourists use their credit cards or mobile phones, and share or post content in social networks, they leave multiple digital footprints that result in a multidimensional data set [19]. Considering limitations about collecting data to study urban tourism [7], this information can be used as a proxy to measure the attractiveness of places as well as the spatial distribution of tourists in the city $[41,50]$. Different types of tourists have different behaviours in using social media and different social media users have different impacts on potential tourists [45].

For instance, from the visitor's perspective, smart user oriented location-based services can lead tourists to the most attractive places-i.e., hotspots [51,52]. Social media can reflect and influence tourists' perceptions and approaches concerning green/eco actions. Social media users are expected to be aware of the impact of travel behaviours and to look for the most sustainable alternatives [45]. From the city's perspective, management information systems-i.e., business intelligence-allows the distributed generation of specific knowledge, relevant to those that manage destinations and to private/public stakeholders [53,54].

Some empirical studies have led to identifying the spatial patterns of city tourists by analysing data from social media [55-57]. However, few attempts have explored the factors that can explain this observed spatial pattern. Thus, the aim of this study is to (1) analyse the spatial distribution of tourists in Lisbon based on data collected from the 'Panoramio' social network, and (2) to explore some relations between the observed pattern and a set of variables related to the city tourism offer. This data embedded in the new ICT context supports the exploration of patterns, while contributing to the understanding of urban tourism spatial production and consumption.

The geotagged photos published by tourists on 'Panoramio' - based on visits from 2008 to 2014-have allowed us to reach a quantitative and geographic perspective on the city's tourist consumption: Which are the most visited city areas? What is their location in the urban context?

From the analysis of a set of online tourist guides related to the city of Lisbon, it is also possible to identify the most referred locations for tourists. This shows us how Lisbon is presented as a tourist destination and the differentiated attractiveness of the places to visit, based on the indications and preferences from tourist online guides that hence constitute an approach from the city's tourist production perspective.

\section{Materials and Methods}

\subsection{Study Area}

Centrally located in the metropolitan area of Lisbon (LMA), the city of Lisbon (Figure 1) has an area of about $85 \mathrm{~km}^{2}$ and 547,773 inhabitants [58]. Lisbon is regarded as the urban centrality of the LMA according to the Strategic Plan for Tourism in the Lisbon Region (PETRL) 2015-2019 [59]; the city is one of the tourist regional centres, showcasing itself as a strong international brand that acts as an anchor of the remaining centralities (Cascais, Sintra, Arrábida, and Arco do Tejo [Tagus Axe]).

Regarding tourism demand statistics, in 2016, the LMA concentrated $24.9 \%$ of total overnight stays in the country. The region continues to be among the first choices for major external markets, being the main destination for Brazilians, North Americans, and Italians. Concerning the internal market, it is the second destination of choice for nationals (with 19.8\% of total overnight stays) [60]. 
In 2014, the average stay of foreign guests in the city of Lisbon was of 2.5 nights, below the average of the LMA (2.6 nights) and mainland Portugal (3.1 nights) [61].

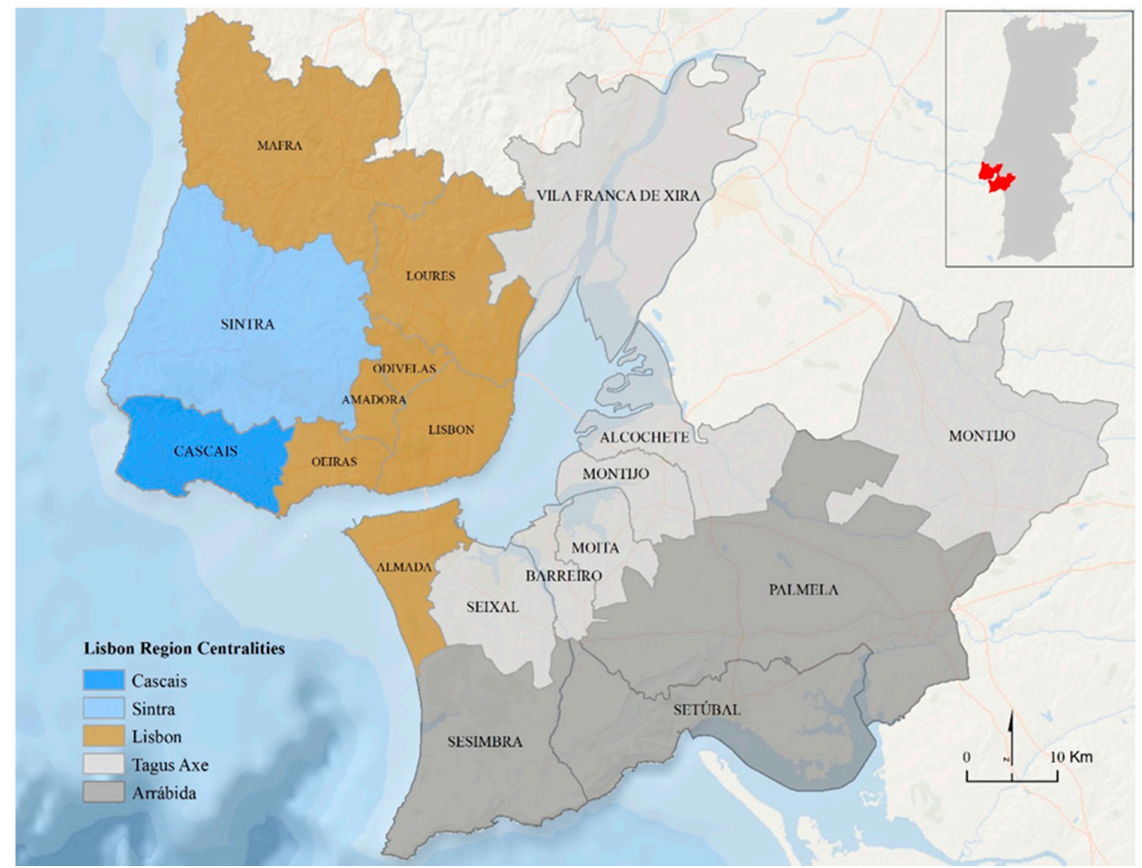

Figure 1. Lisbon Region Centralities [59].

Some areas of the city contribute most to its overall touristic appeal. These areas-also called micro-centralities (MC), following the proposed zoning in the PETRL 2015-2019 (Figure 2 and Table 1) - are situated in three different locations, from the southwest, in Belém, crossing the historic nucleus, in the city centre, to the northeast part of the city, in Parque das Nações.

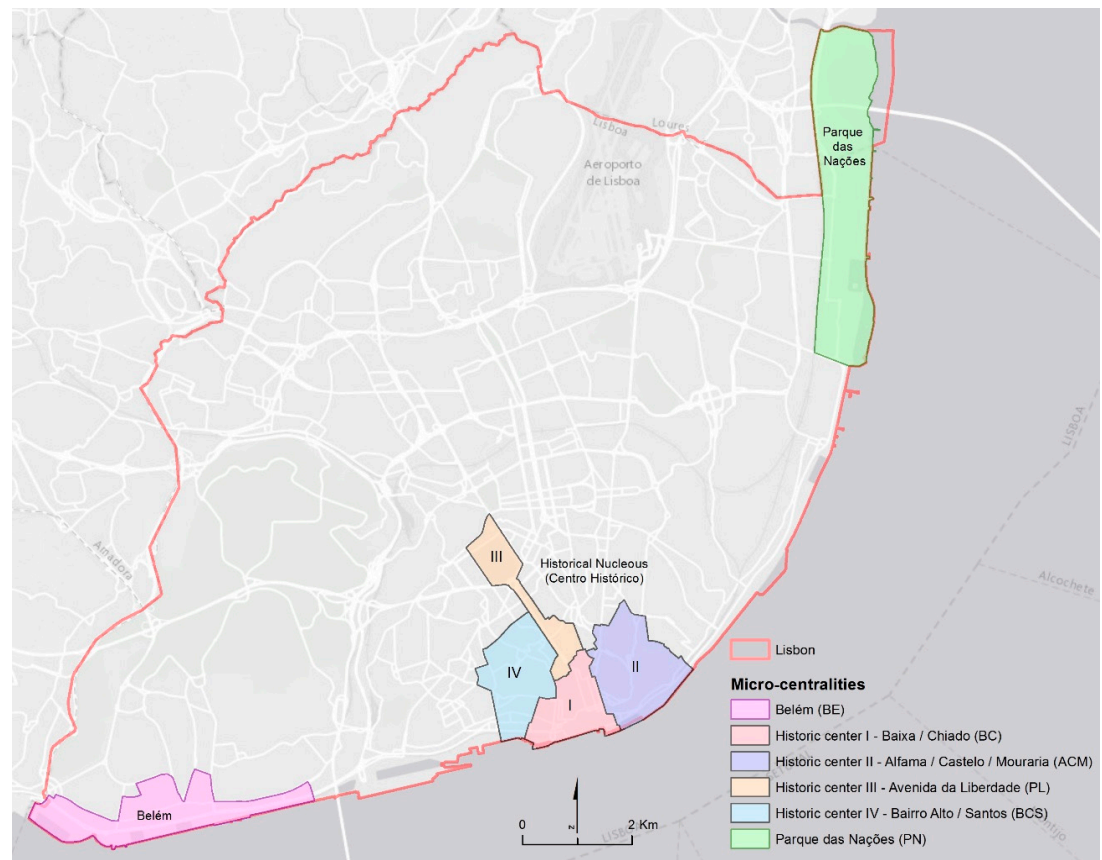

Figure 2. Tourism Micro-centralities in Lisbon [59]. 
According to the survey of tourist's motivations [62] and the survey of visitor's activities [63] — both conducted in 2014 by the Tourism Observatory of Lisbon at the international and national levels-'City \& short break' is considered the largest motivation for visiting Lisbon. For about two-thirds of those surveyed, the city of Lisbon was their only travel destination $(64.1 \%$ of these were first-comers). Visiting monuments, attractions or museums was their preferred activity, particularly in the case of 'First-comers' (81.3\%) in comparison with repeaters (66.3\%).

There is a predominant interest for sites within the city, and those located in the MC Belém and Baixa Chiado had the highest number of visits (Table 1). From these surveys, the importance of the historical-monumental nucleus is also clear, from which Belém and Saint Jorge Castle stand out as the most visited attractions.

Table 1. Places of interest and visited attractions-Survey of visitors' activities [63].

\begin{tabular}{cccccc}
\hline MC & Places of Interest & $\%$ & Places Visited & $\%$ & MC \\
\hline BE & Belém & 79.8 & Belém Tower & 87.1 & BE \\
BC & Baixa & 74.9 & Jerónimos Monastery & 71.9 & BE \\
PN & Parque das Nações & 72.6 & Saint Jorge Castle & 63.5 & ACM \\
BC & Terreiro do Paço & 72.1 & Monument of the Discoveries & 63.1 & BE \\
PL & Avenida da Liberdade & 70.3 & Lisbon Oceanarium & 40.6 & PN \\
BCS & Bairro Alto & 67.2 & Lisbon Cathedral (Sé) & 37.1 & ACM \\
ACM & Alfama & 64.8 & Ajuda Palace & 28.8 & BE \\
BC & Chiado & 57.0 & Pavilion of Knowledge & 23.8 & PN \\
& & & Belém Cultural Centre & 21.6 & BE \\
& & & Gulbenkian Museum & 14.7 & PL \\
& & & Lisbon Casino & 11.8 & PN \\
& & & Ancient Art Museum & 10.5 & BCS \\
& & Coaches Museum & 10.4 & BE \\
& & Chiado Museum & 8.6 & BC \\
& & Design Museum (MUDE) & 2.8 & BC \\
& & Lisbon Story Centre & 2.2 & BC \\
\hline
\end{tabular}

\subsection{Data Retrieving Process and Data Aggregation}

In order to retrieve the photos from 'Panoramio', the study area was segmented into smaller subareas. For each new segment, we extracted the information of the posted photos within its extent. First, the study area was segmented into a lattice of $1000 \mathrm{~m} \times 1000 \mathrm{~m}$ squares. This resulted in 49,048 records. This process was subsequently repeated with increasingly smaller tiles (reaching 22 iterations) until the number of retrieved photos stabilised, i.e., the last tests resulted in a similar number of photos. The final database counted on more than 70,000 records.

The method to differentiate the photos taken by visitors from the ones taken by locals was based on the work carried out by Girardin et al. [55], Kádár [56], and García-Palomares et al. [57]. The authors calculated the difference (in days) between the timestamp of the first and the last uploaded photo by each user. If the resulting number exceeded the average visit time associated with the destination, the photos were considered as belonging to locals; conversely, if the number was beyond the time-period, the photos were catalogued as belonging to visitors.

The resulting dataset consists of 17,604 uploaded photos taken by users that were considered visitors. The location of those photographs is depicted in Figure 3. At first glance, some areas are clearly more prominent than others, i.e., they present a higher concentration of uploaded photos, thus highlighting the most visited/photographed places in the city. 


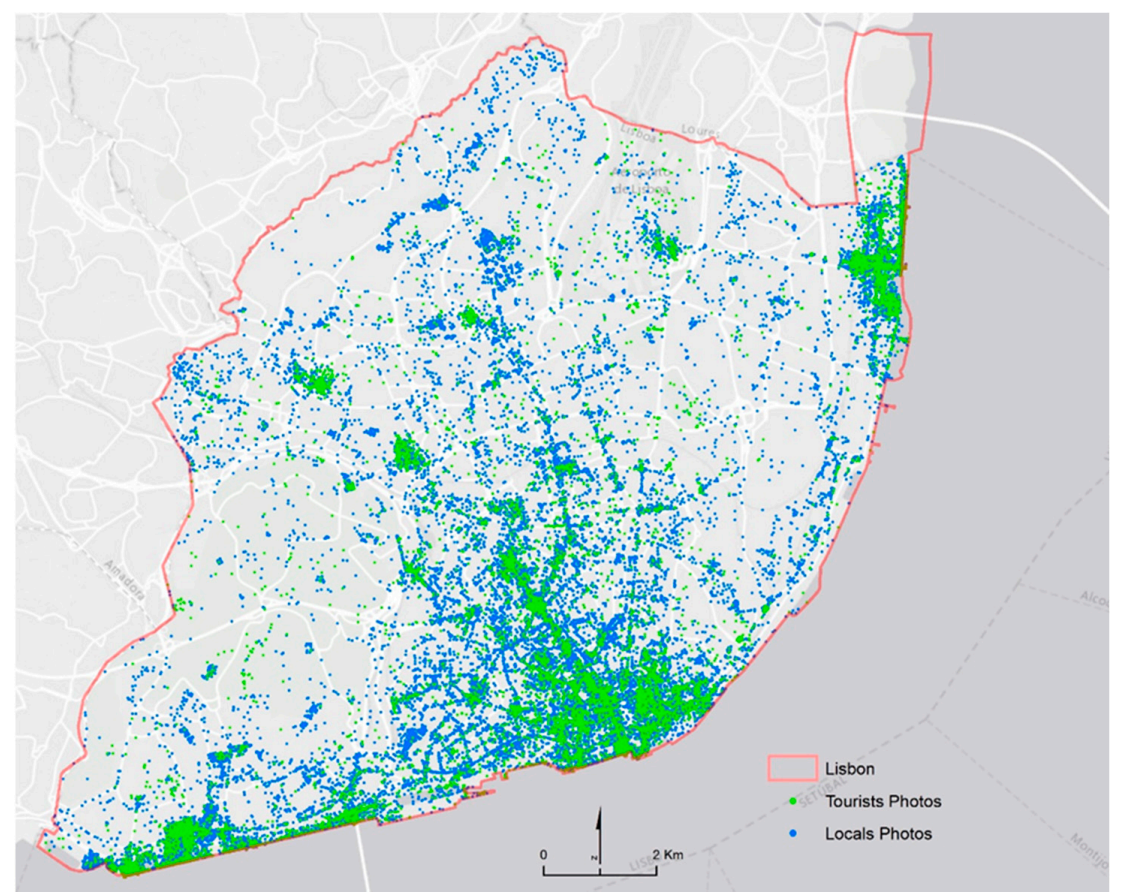

Figure 3. Photos taken in Lisbon between 2008 and 2014, and uploaded on 'Panoramio'.

For the statistical analysis, the dataset was aggregated from a point layer to a regular grid of hexagons with $\approx 2500 \mathrm{~m}^{2}$ each. The value assigned to each of the hexagonal units corresponds to the sum of the individual observations within each cell (Figure 4).

For the multiple regression analysis, the data was aggregated considering the basic units for census purposes, called 'subsections'.

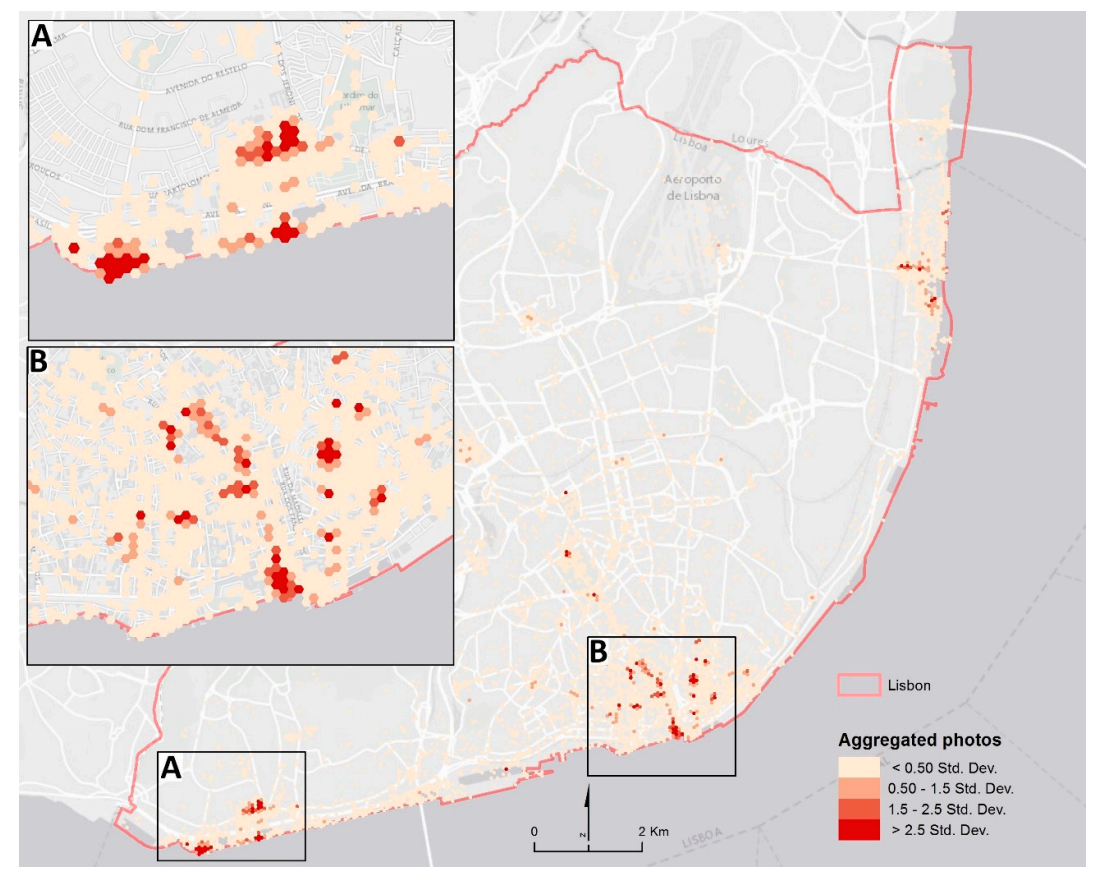

Figure 4. Aggregated tourist photos, taken in Lisbon between 2008 and 2014 and uploaded on 'Panoramio'. Boxes A (Belém) and B (Historic centre) show zoom frames of the two most visited areas. 


\subsection{Cluster and Outlier Analysis}

The Cluster and Outlier analysis is based on the Local Moran Index [64], which enables the identification of local patterns of spatial association. This indicator distinguishes the relationship between the attribute value of an entity and the values corresponding to the entities in its neighbourhood, and is also able to identify the extent of the spatial concentration of similar values for each observation.

In order to perform the analysis, it is necessary to define the neighbourhood area (area surrounding entities to compare) for each target feature and the nature of the spatial relationship between entities.

The neighbourhood was represented on a spatial weight matrix. Following Tobler's first Law of Geography, which states that everything is related to everything but near things are probably more related that distant ones, the inverse distance was chosen to conceptualise the relationship between spatial observations. Thus, the influence of the neighbouring features will decrease as the distance between them increases. Assuming that not all uploads within the study area are spatially related, a threshold for the neighbourhood radius of influence was determined $(150 \mathrm{~m})$.

\subsection{Multiple Linear Regression}

In order to explore the relationships between the observed pattern of tourists' photos and a set of 24 selected variables related to the city's tourist offer, e.g., attractions, services and facilities, a multiple linear regression analysis was carried out. One of the first things to consider in the implementation of a linear regression model is the selection of explanatory factors (variables). A single additional independent variable can improve the prediction of the dependent variable and therefore they must be chosen carefully. Here, 24 variables were selected to be used as independent variables (Table 2), i.e., as explanatory factors of the geographical agglomeration of photos.

Table 2. Pre-selected explanatory variables.

\begin{tabular}{cccc}
\hline Code & Variable & Code & Variable \\
\hline V1 & Civil architecture & V13 & Hospitality (Accommodation) \\
V2 & Industrial architecture & V14 & Churches \\
V3 & Military architecture & V15 & Markets \\
V4 & Noble architecture & V16 & Viewpoints \\
V5 & Award-winning architecture & V17 & Monuments of public interest \\
V6 & Religious architecture & V18 & National monuments \\
V7 & Cemeteries & V19 & Museums \\
V8 & Blocks of public interest & V20 & Playgrounds \\
V9 & Leisure docks and marinas & V21 & Picnic parks \\
V10 & Funiculars and lifts & V22 & Leisure parks \\
V11 & Fairs & V23 & Urban parks \\
V12 & Geo-monuments & V24 & Theatres \\
\hline
\end{tabular}

Spatially, all these variables were represented in a point layer. Subsequently, all variables were transformed into reason scales by applying the Inverse Euclidean Distance to the parsed element. As the unit of measurement is always the same (metres), there was no need to standardise values. In order to illustrate the transformation of the variables, the map with the Inverse Euclidean Distance to the features of the variable 'Viewpoints' (V16) is presented in Figure 5.

The predictive performance of a linear regression model is not only related to the correlation of the dependent variable with a certain (independent) variable, but also to the correlation of the former with all the other independent variables. Thus, the possible dependencies among all the variables should be assessed. In cases where these dependencies between variables are strong, one can state that there is a multicollinearity process. 


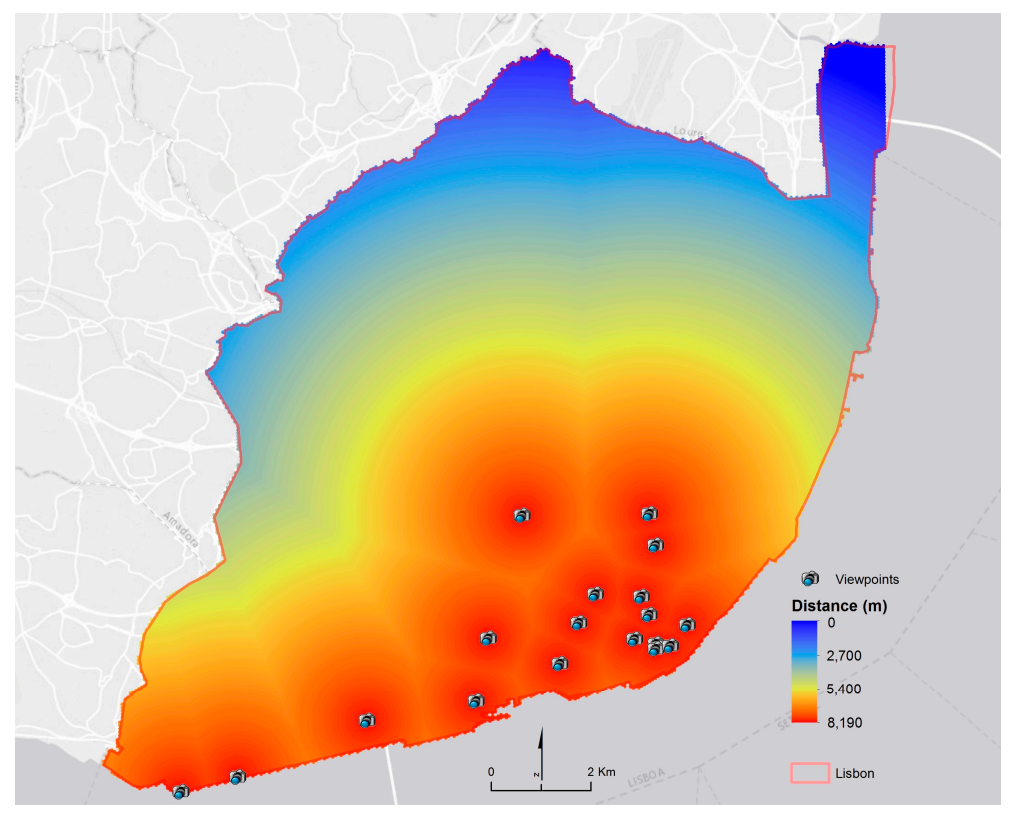

Figure 5. Inverse Euclidean Distance to viewpoint features.

As collinearity means that some independent variables are correlated, it can be detected, among different ways, through the array of correlations that exist between them. The Pearson correlation coefficients between independent variables were calculated. Only variables with $r>-0.85$ or $r<0.85$ correlations were included in the regression model without the risk of high multicollinearity [65]. Looking at Figure 6, one can see that strong positive relations are predominant, whereas negative relations are only moderate.

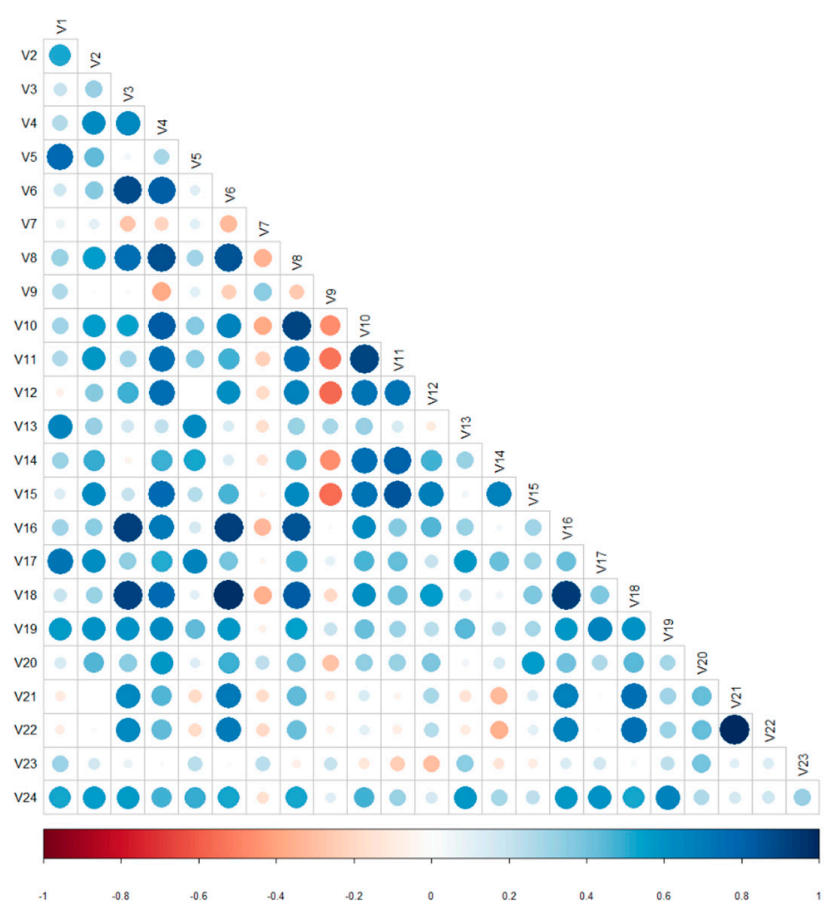

Figure 6. Pearson correlation coefficient between the 24 pre-selected explanatory variables.

Another technique used was the tolerance value or its inverse, known as Variance Inflation Factor (VIF), whose high values indicate the existence of multicollinearity. The VIF is a measure of the degree 
to which each independent (temporarily transformed in dependent) variable is explained by all the other independent variables [66]. The greater the VIF, the more severe will be the multicollinearity. Thus, the VIF measures the redundancy between all explanatory variables. Explanatory variables with VIF values above 7.5 were removed (one by one) from the regression model $[66,67]$. Table 3 shows VIF values for each of the 24 pre-selected variables. Of these, 12 were excluded for presenting VIF values above the defined threshold.

Table 3. Variance Inflation Factor (VIF) and frequency values.

\begin{tabular}{cccc}
\hline Code & Variable & VIF & Frequency \\
\hline V23 & Urban parks & 2.99 & 0 \\
V7 & Cemeteries & 3.50 & 0 \\
V17 & Monuments of public Interest & 3.96 & 1 \\
V20 & Playgrounds & 4.14 & 3 \\
V24 & Theatres & 4.27 & 1 \\
V5 & Award-winning architecture & 4.50 & 1 \\
V1 & Civil architecture & 5.39 & 0 \\
V12 & Geo-monuments & 5.70 & 21 \\
V2 & Industrial architecture & 5.87 & 0 \\
V13 & Hospitality (Accommodation) & 6.16 & 33 \\
V19 & Museums & 6.25 & 0 \\
V9 & Leisure docks and marinas & 6.70 & 6 \\
V15 & Markets & 10.31 & 8 \\
V4 & Noble architecture & 16.83 & 1 \\
V14 & Churches & 16.87 & 32 \\
V3 & Military architecture & 20.85 & 0 \\
V11 & Fairs & 22.37 & 0 \\
V6 & Religious architecture & 45.08 & 0 \\
V16 & Viewpoints (Belvederes) & 58.24 & 2 \\
V18 & National monuments & 58.77 & 0 \\
V8 & Blocks of public interest & 104.93 & 0 \\
V10 & Funiculars and lifts & 114.61 & 29 \\
V21 & Picnic parks & 359.06 & 5 \\
V22 & Leisure parks & 442.87 & 5 \\
\hline
\end{tabular}

Complementarily, an exploratory analysis was performed in which the dependent variable was modelled against sets of 1 to 5 independent variables. Overall, 35,526 combinations were tested, 6866 of which presented an $R^{2}$ greater than 0.90 . Within this group, the 38 best performing models always used 5 variables, with predictive performances between 0.95 and 0.96 . Table 3 also identifies the variables that were most frequently selected in the testing models.

The cross-tabulation between VIF values and frequencies (Table 3), i.e., variables with a higher frequency but with low VIF values, guided the final selection of 7 independent variables to customise the model (Table 4).

Table 4. Multiple Linear Regression final variables selection.

\begin{tabular}{ccc}
\hline Code & Variable & Weight \\
\hline V13 & Hospitality & 0.10 \\
V12 & Geo-monuments & 0.12 \\
V9 & Leisure docks and marinas & 0.21 \\
V20 & Playgrounds & 0.03 \\
V5 & Award-winning architecture & 0.15 \\
V17 & Monuments of public interest & 0.29 \\
V24 & Theatres & 0.10 \\
\hline
\end{tabular}


$R^{2}$ and adjusted $R^{2}$ measures were verified as performance indicators of the model. As a final result, the regression achieved values of $R^{2}=0.6828$ and adjusted $R^{2}=0.6827$, which means the model is able to represent about $68 \%$ of the spatial variation of the total amount of tourists' photos.

\section{Results}

\subsection{Analysis by Micro-Centralities}

Taking into account the micro-centralities defined according to the zoning proposed in the 2015-2019 PETRL, it is possible to identify tourist preferences regarding some places of the city that are perceived as areas of interest (Figure 7). In fact, $75 \%$ of the photos were taken within the boundaries of those areas defined as micro-centralities. This number is divided between the historic centre, the main focus of tourists' photos (more than $40 \%$ of overall photos), Belém (about 20\%), and Parque das Nações (with 12\%).
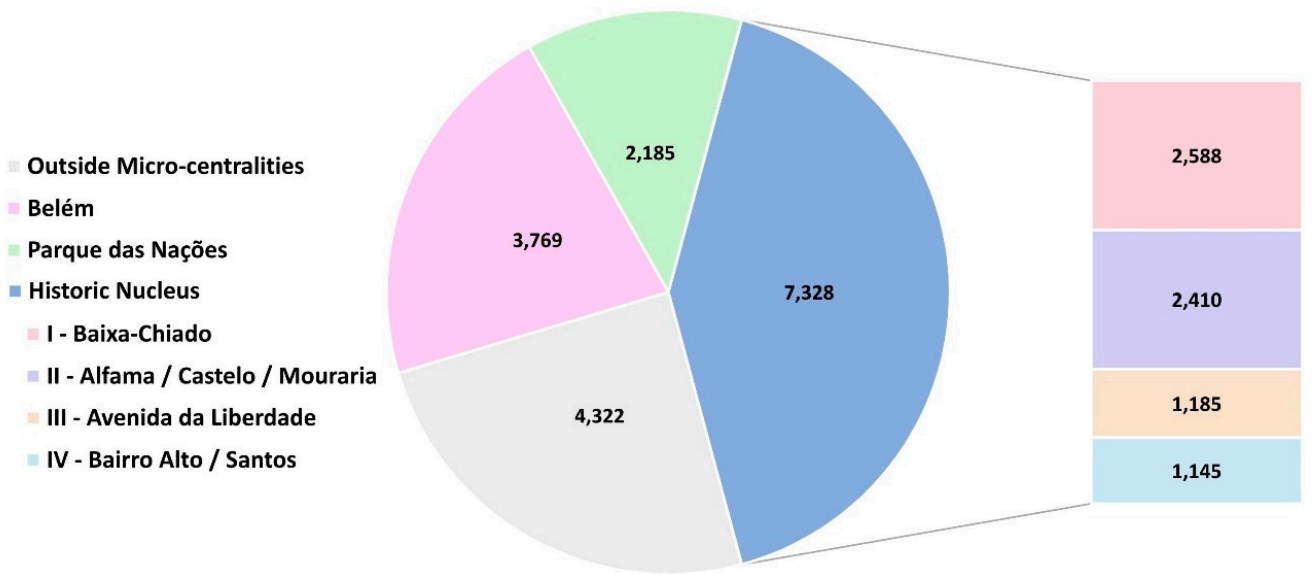

Figure 7. Number of photos per micro-centralities.

Despite the predominance of the historic centre, the distribution of the photographs within its limits is geographically asymmetric and the predominance of two subareas over the others can be clearly noted. In this context, MC I (Baixa-Chiado) and II (Alfama/Castelo/Mouraria), with respectively $35 \%$ and $32 \%$ of the total number of photos taken in the historic centre, differ from the others, MC III (Avenida da Liberdade) with 16\% and MC IV (Bairro Alto/Santos) with 15\%.

\subsection{Clusters and Outlier Analysis}

As expected, clusters are located within the tourist areas (MC) of the city, mostly neighbouring the most relevant attractions. As shown in Section 3.1, when analysing the absolute number of photos, the well-known city tourist areas understandably stand out. However, this approach did not include some key aspects in regards to spatial analysis, as the configuration of the local neighbourhood or the statistical significance of the data.

As shown in Figure 8, the most striking fact is that almost all of the significant spatial clusters belong to the High-High $(\mathrm{HH})$ category, i.e., they correspond to places where high values are surrounded by similar values. Therefore, there is a large presence of visitors, both in these locations and in their contiguous areas. 


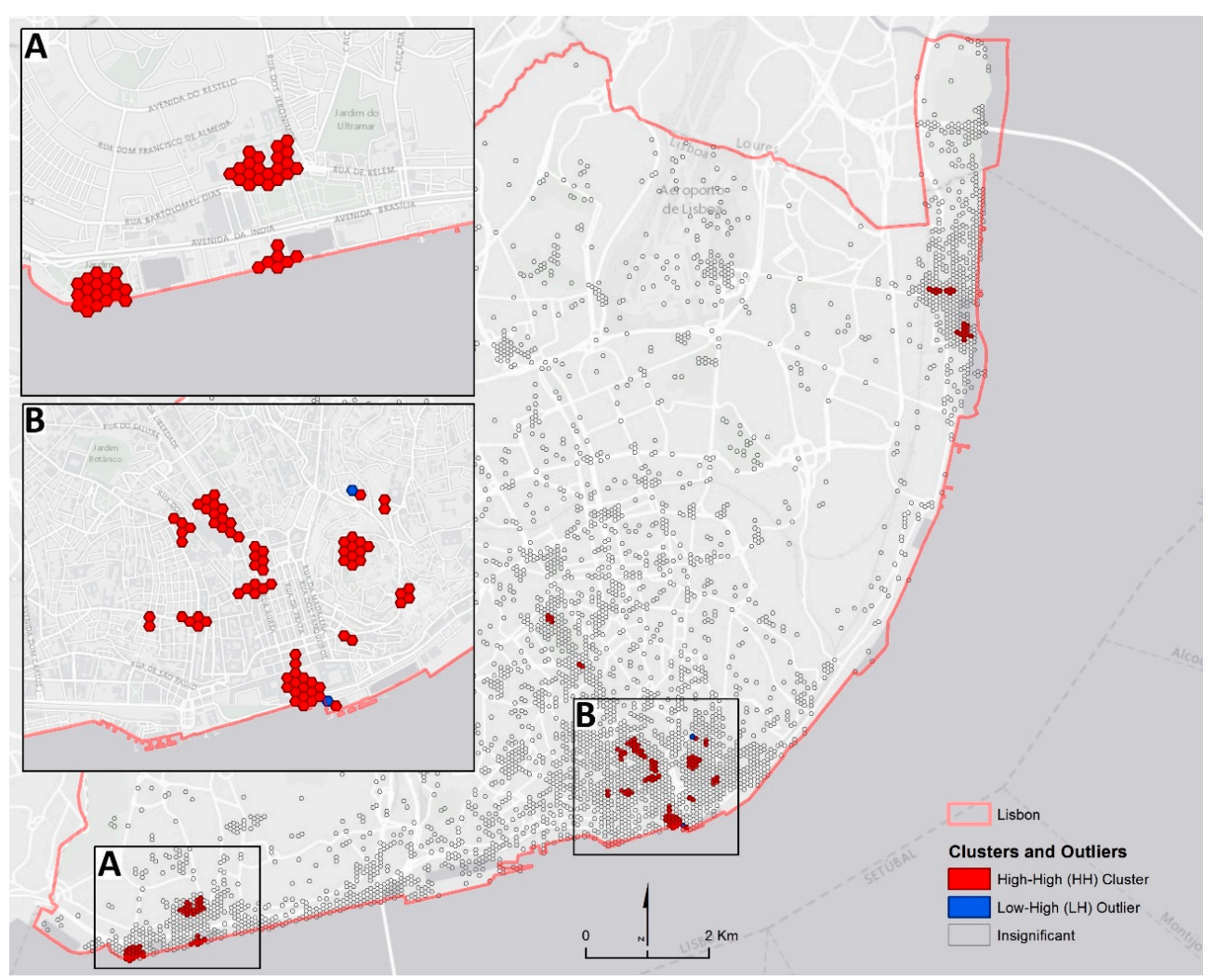

Figure 8. Clusters and outliers of tourists' photos in Lisbon. Boxes A (Belém) and B (Historic centre) show zoom frames of the two most visited areas.

On the other hand, only two clusters represent a different category-Low-High (LH)—and refer to those locations which specifically do not have that many visitors but that are characterized by significant numbers of visitors in their neighbourhoods.. Therefore, these particular spots are less visited than the areas surrounding them.

In fact, it turns out that tourist attractions-e.g., squares, viewpoints, monumental architecture-function as the main focus of spatial clusters. It is around them that clusters take form, and it is from them that these expand to nearby areas. In many cases, the clusters' expansion follows the physical shape of the attractions (e.g., squares), extending beyond their perimeter.

The Local Moran Index was calculated (Figure 9) to understand the difference between spatial clusters with regards to their magnitude.

The higher values of the index are associated with locations around or in the neighbourhood of the attractions (e.g., Belém Tower and the Monument of the Discoveries to the south, and Praça do Marquês de Pombal in the historic centre). In the case of the Jerónimos Monastery and the Lisbon Oceanarium, the more differentiated values correspond to places located at the front, in the area near the entrances.

Regarding clusters on squares (e.g., 'Restauradores', 'Dom Pedro IV', 'Comércio' and 'Luís de Camões' squares), the most predominant values of the index tend to be closer to the centre. For instance, in the 'Restauradores' and 'Dom Pedro IV' squares, the central area clearly stands out. 


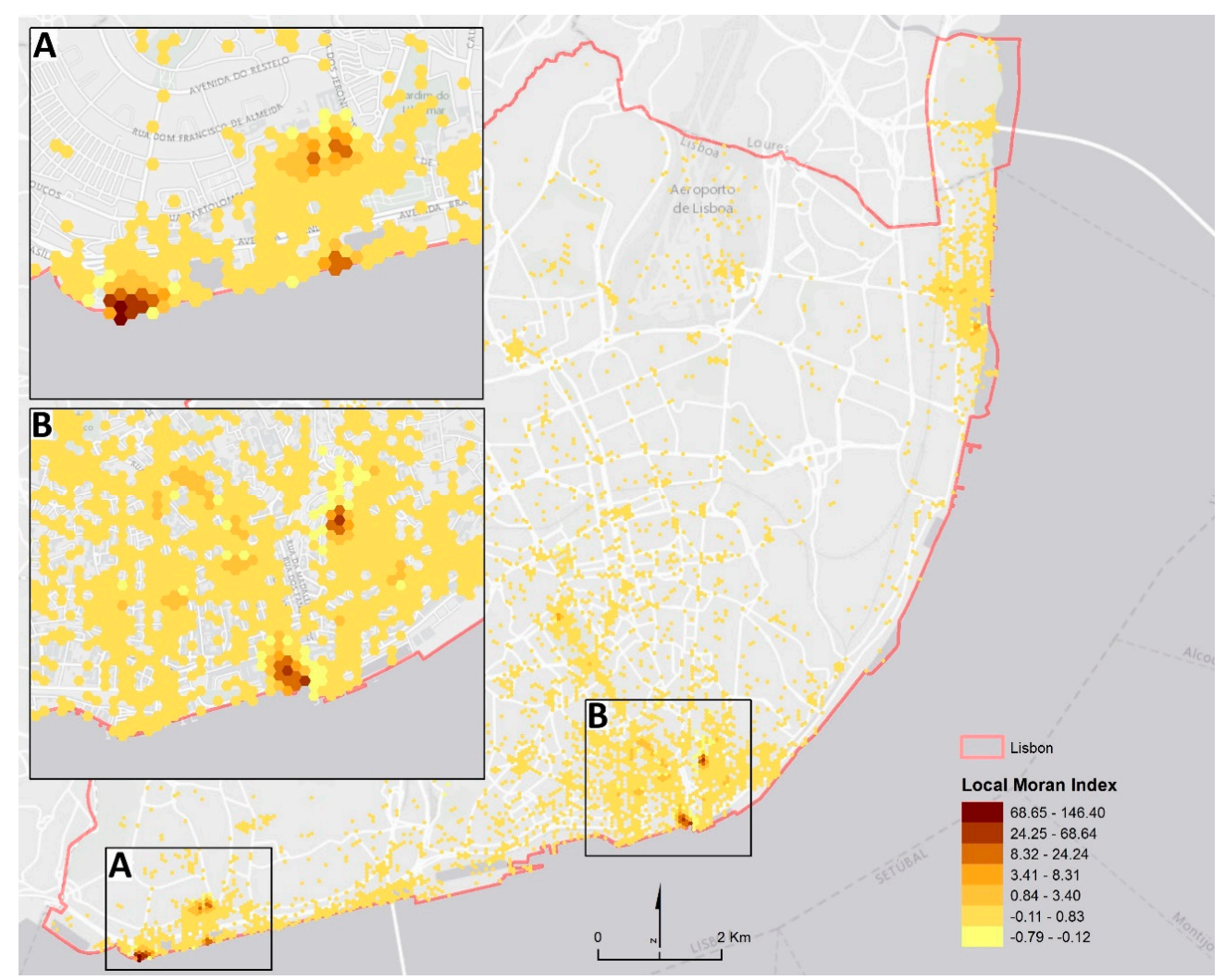

Figure 9. Local Moran Index. Boxes A (Belém) and B (Historic centre) show zoom frames of the two most visited areas.

\subsection{Multiple Linear Regression Analysis}

From the Multiple Linear Regression (MLR) analysis, one can identify the most relevant factors, and their importance (weights), thus explaining the spatial distribution of photographs. The resulting explanatory factors are the proximity to: Public monuments (0.29); Leisure docks and marinas (0.21); Award-winning architecture (0.15); Geo-monuments (0.12); Hospitality (Accommodation) (0.10); and Theatres (0.10). However, beyond the analysis of these factors and the prediction model itself, the analysis of the residuals is also interesting for tourism planning purposes.

The residuals analysis is precisely a technique used to check the suitability of a regression model. The basic idea of the residuals analysis is that if the model fits, the residuals should reflect the properties of the model error, i.e., positive residuals reveal results above the predicted values and negative residuals indicate the opposite.

In practice, what 'residuals' means is that, given the observed conditions-i.e., the 7 explanatory factors-there are areas where the number of pictures is higher than expected (positive residuals) and others with fewer pictures than would be expected (negative residuals). Therefore, those deficit areas may require some assistance in terms of planning in order to reach their full potential.

In the south of Lisbon, Belém stands out with values above its potential (Figure 10). Unexpectedly, the downtown area (Baixa-Chiado), albeit having appeared in all the previous analyses as a major hot spot, is still below its potential. The Parque das Nações area follows the same trend but without a prominent disparity. However, they are clearly two micro-centralities identified by the Tourism Bureau that may be the subject of planning actions targeted at attracting more visitors. 


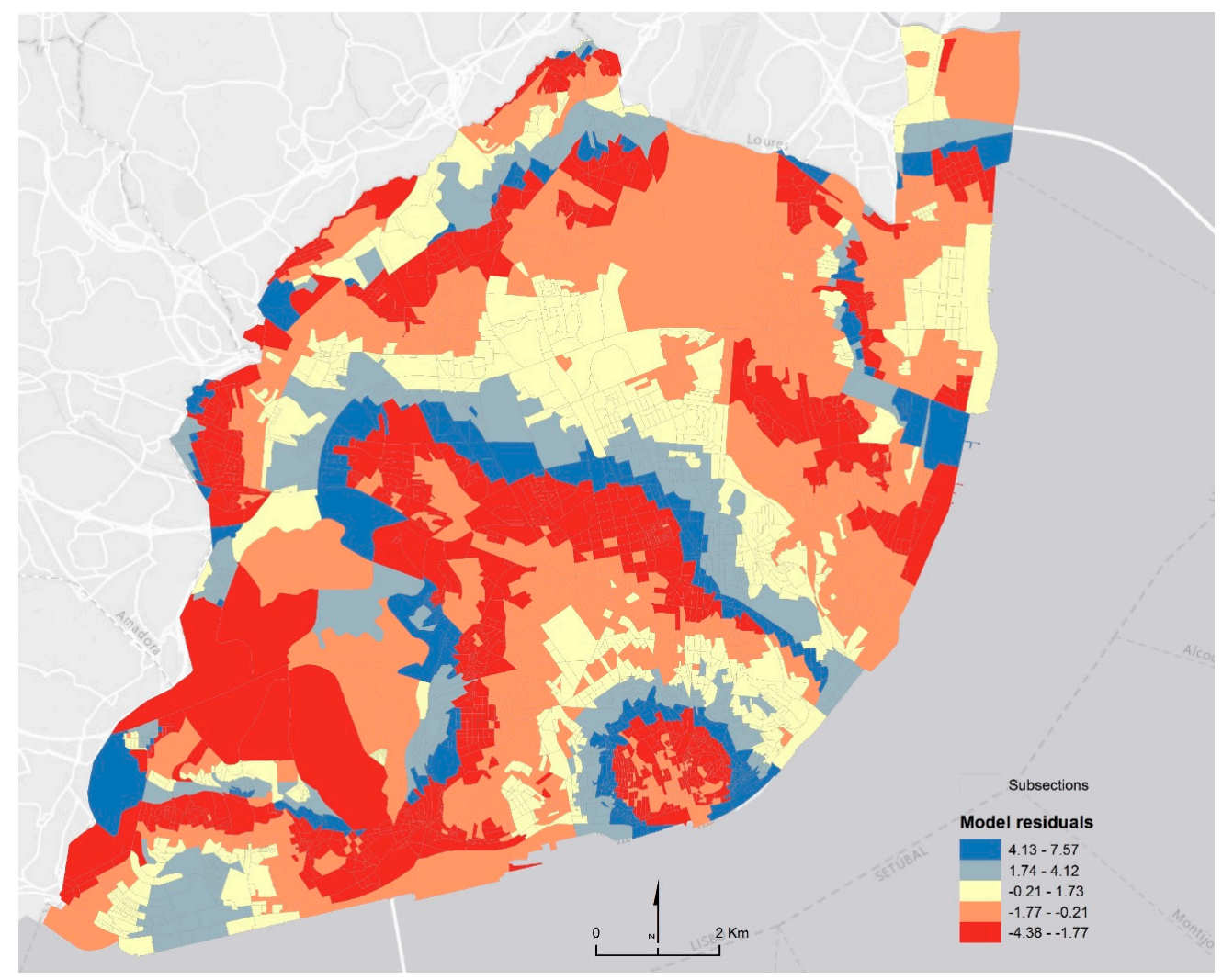

Figure 10. Residuals of the Multiple Linear Regression model.

\section{Discussion}

Online photographs published by visitors make it possible to identify and analyse visual tourist places of interest within the city. Most studies based on information gathered from social networking sites have been limited to creating products, e.g., maps and animations. The results show that the photographs taken by tourists reveal higher spatial concentration than those obtained by residents.

The comparison between the spatial clusters of photos and the main tourist attractions (within the micro-centralities) indicates that the results are consistent, since the spatial clusters match the places of the city that are known to attract more tourists.

The data set (17,604 observations used in this analysis) retrieved from the 'Panoramio' social network provides a robust sample that reproduces the city tourist areas, frequently experienced by non-locals. Although there is a growing trend among tourists to share their travel experiences through social networks, this data only partially represents the actual tourism demand.

The spatial distribution of tourists is not homogeneous. In an attempt to clarify the factors that stimulate the variation of the spatial process, it is confirmed that monuments of public interest (together with six other factors) are the elements that best explain the geographical agglomeration of photographs. Although the model reached $68 \%$ of the phenomenon explanation, the findings shown by regression residuals should be considered, as well as their potential contribution for tourism management. According to the regression model, there are areas within micro-centralities whose tourism potential is underestimated. These areas may need future intervention in terms of public facilities, activities, or services. Since this is an empirical approach to explore the potential relations between a set of possible factors associated to the tourist offer, further explanatory research has to be conducted to test the model resulting factors and their level of importance (weight).

The definition of tourist areas can largely benefit from the Tourism 2.0 potential, namely by analysing the concentration of the tourists' digital imprints through location-based information, such 
as photos shared in social networks. It is possible to highlight which areas are more attractive to visitors and, more importantly, their relevant features. Yet, some areas may not be regarded as tourist attractions by local authorities despite their high potential for tourist activities. Knowing which areas are under tourist pressure effectively contributes to tourism and city management and competitiveness, providing decision-makers with improved tools to design better, smarter, and sustainable strategies; also contributes to optimise tourists' experience, which should be, ultimately, the goal of a smart tourism destination.

\section{Conclusions}

The widespread use of ICTs-such as cloud computing with high processing performance, the IoT, and data mining - has created different dimensions for tourism. Smartness is a key factor in achieving sustainable development [68] and contributes to advances in tourism [19,27], but also in society as a whole. Indeed, the added value of smart tourism is innovation, technology, and sustainability $[26,27,30]$.

The smart city concept therefore encompasses a wide application of sustainability principles to urban competitiveness [18], referring both to the use of ICTs and to the quality of the soft smartness components [20].

Since the smart city approach is grounded on the assumption that technology is part of the system, the use of technological solutions in decision-making processes based on evidence effectively contributes to ranking necessary actions and predicting future scenarios, which is crucial for a responsible, smart, and sustainable management of tourism and its impacts. Thanks to these new solutions involving smart tools, cities can improve access to tourist spots, and explore the prospects and challenges presented by crowdsourced and open data platforms. Smart tourism is a key contributor to a new "sensor society" [69] that is regarded as always based on extensive (big) data capture.

ICT platforms, sensor networks, and wireless communication systems form the basis for an integration and data exchange approach [30] and contribute to the overall strategic planning process by facilitating the transformation of tacit knowledge into explicit organised knowledge [70]. However, the integration of technology within a tourism destination is not the sole condition for becoming smart, and thus the goal is to integrate the whole range of smartness components. For that, ICTs should be complemented with information provided by experts, including government officials and researchers, in order develop an evaluation system for quality management in tourist attractions [71]. Nevertheless, smart tourism draws attention to some issues regarding information governance [72] and appropriately extracting the value of information. Another issue is technology-dependence. This has strong consequences in terms of creating a wide digital split between those with or without smart devices, and between destinations that can or cannot afford smart tourism infrastructures [73]. In this sense, smart tourism infrastructures can lead to new information imbalances [74].

Furthermore, the growing need for information can easily persuade tourists to lose privacy [75]. Smart tourists leave massive digital footprints and the chances for mining their digital traces from travel (whether on holiday or business) are multiple. Therefore, smart tourism environments have to consider the value-in-use [76], i.e., the value created by using data and/or technology instead of owning it.

Acknowledgments: Luis Encalada was financed through a grant of the Institute of Geography and Spatial Planning and Universidade de Lisboa, IGOT-UL (BD2016).

Author Contributions: Luis Encalada, Carlos Cardoso Ferreira and Jorge Rocha analysed the data; Luis Encalada, Inês Boavida-Portugal and Jorge Rocha contributed to the analysis tools; Luis Encalada, Inês Boavida-Portugal, Carlos Cardoso Ferreira and Jorge Rocha wrote the paper.

Conflicts of Interest: The authors declare no conflict of interest. 


\section{References}

1. United Nations. World Urbanization Prospects: The 2014 Revision; ST/ESA/SER.A/366; United Nations: New York, NY, USA, 2015.

2. Organisation for Economic Co-operation and Development (OECD). OECD Environmental Outlook to 2050. The Consequences of Inaction; OECD: Paris, France, 2012; ISBN 9789264122161.

3. Neirotti, P.; De Marco, A.; Cagliano, A.C.; Mangano, G.; Scorrano, F. Current trends in Smart City initiatives: Some stylised facts. Cities 2014, 38, 25-36. [CrossRef]

4. Jurdana, D.S.; Sušilović, Z. Planning city tourism development: Principles and issues. Tour. Hosp. Manag. 2006, 12, 135-144.

5. Hedrick-Wong, Y.; Choong, D. MasterCard 2014 Global Destination Cities Index; MasterCard: Purchase, NY, USA, 2014.

6. Euromonitor International. Top 100 City Destinations Ranking; Euromonitor International: London, UK, 2014.

7. Ashworth, G.; Page, S.J. Urban tourism research: Recent progress and current paradoxes. Tour. Manag. 2011, 32, 1-15. [CrossRef]

8. World Tourism Organization. Global Report on City Tourism-Cities 2012 Project; World Tourism Organization: Madrid, Spain, 2012.

9. Falconer, G.; Mitchell, S. Smart City Framework: A Systematic Process for Enabling Smart+ Connected Communities; Cisco Internet Business Solutions Group (IBSG): San Jose, CA, USA, 2012.

10. Colldahl, C.; Frey, S.; Kelemen, J.E. Smart Cities: Strategic Sustainable Development for an Urban World; Blekinge Institute of Technology: Karlskrona, Sweden, 2013.

11. Caragliu, A.; Del Bo, C.; Nijkamp, P. Smart Cities in Europe. J. Urban Technol. 2011, 18, 65-82. [CrossRef]

12. Datta, A. A 100 smart cities, a 100 utopias. Dialogues Hum. Geogr. 2015, 5, 49-53. [CrossRef]

13. Kummitha, R.K.R.; Crutzen, N. How do we understand smart cities? An evolutionary perspective. Cities 2017, 67, 43-52. [CrossRef]

14. Kourtit, K.; Nijkamp, P. Smart cities in the innovation age. Innov. Eur. J. Soc. Sci. Res. 2012, 25, 93-95. [CrossRef]

15. Gibbs, D.; Krueger, R.; MacLeod, G. Grappling with Smart City Politics in an Era of Market Triumphalism. Urban Stud. 2013, 50, 2151-2157. [CrossRef]

16. Cugurullo, F. How to Build a Sandcastle: An Analysis of the Genesis and Development of Masdar City. J. Urban Technol. 2013, 20, 23-37. [CrossRef]

17. Calzada, I.; Cobo, C. Unplugging: Deconstructing the Smart City. J. Urban Technol. 2015, 22, 23-43. [CrossRef]

18. Angelidou, M. Smart cities: A conjuncture of four forces. Cities 2015, 47, 95-106. [CrossRef]

19. Buhalis, D.; Amaranggana, A. Smart Tourism Destinations BT. In Information and Communication Technologies in Tourism 2014, Proceedings of the International Conference, Dublin, Ireland, 21-24 January 2014; Xiang, Z., Tussyadiah, I., Eds.; Springer International Publishing: Cham, Switzerland, 2013; pp. 553-564.

20. Batty, M.; Axhausen, K.W.; Giannotti, F.; Pozdnoukhov, A.; Bazzani, A.; Wachowicz, M.; Ouzounis, G.; Portugali, Y. Smart cities of the future. Eur. Phys. J. Spec. Top. 2012, 214, 481-518. [CrossRef]

21. Mills, J.E.; Law, R. Handbook of Consumer Behavior, Tourism and the Internet; Haworth Press Inc.: Binghamton, NY, USA, 2005; ISBN 078902599X.

22. Gretzel, U. Intelligent systems in tourism: A Social Science Perspective. Ann. Tour. Res. 2011, 38, 757-779. [CrossRef]

23. Vicini, S.; Bellini, S.; Sanna, A. How to Co-Create Internet of Things-enabled Services for Smarter Cities. In SMART 2012: The First International Conference on Smart Systems, Devices and Technologies; IARIA: Stuttgart, Germany, 2012; pp. 55-61.

24. Cacho, A.; Figueredo, M.; Cassio, A.; Araujo, M.V.; Mendes, L.; Lucas, J.; Farias, H.; Coelho, J.; Cacho, N.; Prolo, C. Social Smart Destination: A Platform to Analyze User Generated Content in Smart Tourism Destinations. In New Advances in Information Systems and Technologies; Rocha, Á., Correia, A.M., Adeli, H., Reis, L.P., Mendonça Teixeira, M., Eds.; Springer International Publishing: Cham, Switzerland, 2016; pp. 817-826. ISBN 978-3-319-31232-3.

25. World Tourism Organization (UNWTO). Report of the First Meeting of the UNWTO Tourism Resilience Committee; UNWTO: Madrid, Spain, 2009; pp. 1-41. 
26. La Rocca, R.A. The Role of Tourism in Planning the Smart City. Tema. J. Land Use Mobil. Environ. 2014, 7 , 269-284. [CrossRef]

27. Boes, K.; Buhalis, D.; Inversini, A. Smart tourism destinations: Ecosystems for tourism destination competitiveness. Int. J. Tour. Cities 2016, 2, 108-124. [CrossRef]

28. Bakhtin, M.M. The Dialogic Imagination: Four Essays; University of Texas Press: Austin, TX, USA, 1983.

29. Ooi, C.-S. Contrasting strategies: Tourism in Denmark and Singapore. Ann. Tour. Res. 2002, 29, 689-706. [CrossRef]

30. Gretzel, U.; Werthner, H.; Koo, C.; Lamsfus, C. Conceptual foundations for understanding smart tourism ecosystems. Comput. Hum. Behav. 2015, 50, 558-563. [CrossRef]

31. Fistola, R.; Anna, R.; Rocca, L. Smart City Planning: A Systemic Approach. In Proceedings of the 6th Knowledge Cities World Summit, KCWS 2013, Istanbul, Turkey, 9-12 September 2013; pp. 520-529.

32. Al Nuaimi, E.; Al Neyadi, H.; Mohamed, N.; Al-Jaroodi, J. Applications of big data to smart cities. J. Internet Serv. Appl. 2015, 6, 25. [CrossRef]

33. Kitchin, R. Big Data, new epistemologies and paradigm shifts. Big Data Soc. 2014, 1, 2053951714528481. [CrossRef]

34. Lamsfus, C.; Martín, D.; Alzua-Sorzabal, A.; Torres-Manzanera, E. Smart Tourism Destinations: An Extended Conception of Smart Cities Focusing on Human Mobility. In Information and Communication Technologies in Tourism 2015, Proceedings of the International Conference, Lugano, Switzerland, 3-6 February 2015; Tussyadiah, I., Inversini, A., Eds.; Springer International Publishing: Cham, Switzerland, 2015; pp. 363-375.

35. Guinard, D.; Trifa, V.; Mattern, F.; Wilde, E. From the Internet of Things to the Web of Things: Resource-oriented Architecture and Best Practices. In Architecting the Internet of Things; Uckelmann, D., Harrison, M., Michahelles, F., Eds.; Springer: Berlin/Heidelberg, Germany, 2011; pp. 97-129, ISBN 978-3-642-19157-2.

36. Komninos, N.; Pallot, M.; Schaffers, H. Special Issue on Smart Cities and the Future Internet in Europe. J. Knowl. Econ. 2013, 4, 119-134. [CrossRef]

37. Batty, M. Big data, smart cities and city planning. Dialogues Hum. Geogr. 2013, 3, 274-279. [CrossRef]

38. Yaqoob, I.; Chang, V.; Gani, A.; Mokhtar, S.; Hashem, I.A.T.; Ahmed, E.; Anuar, N.B.; Khan, S.U. Information fusion in social big data: Foundations, state-of-the-art, applications, challenges, and future research directions. Int. J. Inf. Manag. 2016. [CrossRef]

39. Gani, A.; Siddiqa, A.; Shamshirband, S.; Hanum, F. A survey on indexing techniques for big data: Taxonomy and performance evaluation. Knowl. Inf. Syst. 2016, 46, 241-284. [CrossRef]

40. Chen, M.; Mao, S.; Liu, Y. Big Data: A Survey. Mob. Netw. Appl. 2014, 19, 171-209. [CrossRef]

41. Tussyadiah, I.P. An Assessment of Contagion on Social Networking Sites. In Information and Communication Technologies in Tourism 2012, Proceedings of the International Conference, Helsingborg, Sweden, 25-27 January 2012; Fuchs, M., Ricci, F., Cantoni, L., Eds.; Springer: Vienna, Austria, 2012; pp. 25-35.

42. Buhalis, D.; Law, R. Progress in information technology and tourism management: 20 years on and 10 years after the Internet-The state of eTourism research. Tour. Manag. 2008, 29, 609-623. [CrossRef]

43. Sui, D.; Goodchild, M. The convergence of GIS and social media: Challenges for GIScience. Int. J. Geogr. Inf. Sci. 2011, 25, 1737-1748. [CrossRef]

44. Di Minin, E.; Tenkanen, H.; Toivonen, T. Prospects and challenges for social media data in conservation science. Front. Environ. Sci. 2015, 3, 63. [CrossRef]

45. Zeng, B.; Gerritsen, R. What do we know about social media in tourism? A review. Tour. Manag. Perspect. 2014, 10, 27-36. [CrossRef]

46. Mayer-Schönberger, V.; Cukier, K. Big Data: A Revolution that Will Transform How We Live, Work, and Think; An Eamon Dolan Book; Houghton Mifflin Harcourt: Boston, MA, USA, 2013; ISBN 9780544002692.

47. Arts, K.; van der Wal, R.; Adams, W.M. Digital technology and the conservation of nature. Ambio 2015, 44, 661-673. [CrossRef] [PubMed]

48. Hausmann, A.; Toivonen, T.; Slotow, R.; Tenkanen, H.; Moilanen, A.; Heikinheimo, V.; Di Minin, E. Social Media Data Can Be Used to Understand Tourists' Preferences for Nature-Based Experiences in Protected Areas. Conserv. Lett. 2017. [CrossRef]

49. Tufekci, Z. Big Questions for social media big data: Representativeness, validity and other methodological pitfalls. In Proceedings of the 8th International Conference on Weblogs and Social Media, ICWSM 2014, Ann Arbor, MI, USA, 1-4 June 2014; The AAAI Press: Ann Arbor, MI, USA, 2014; pp. 505-514. 
50. MacKay, K.; Vogt, C. Information technology in everyday and vacation contexts. Ann. Tour. Res. 2012, 39, 1380-1401. [CrossRef]

51. Höpken, W.; Fuchs, M.; Zanker, M.; Beer, T. Context-Based Adaptation of Mobile Applications in Tourism. Inf. Technol. Tour. 2010, 12, 175-195. [CrossRef]

52. Fuchs, M.; Höpken, W.; Lexhagen, M. Big data analytics for knowledge generation in tourism destinationsA case from Sweden. J. Destin. Mark. Manag. 2014, 3, 198-209. [CrossRef]

53. Höpken, W.; Fuchs, M.; Lexhagen, M. The knowledge destination-Applying methods of business intelligence to tourism. In Encyclopedia of Business Analytics and Optimization; IGI Glob: Hershey, PA, USA, 2014; pp. 307-321.

54. Fuchs, M.; Eybl, A.; Höpken, W. Successfully selling accommodation packages at online auctions-The case of eBay Austria. Tour. Manag. 2011, 32, 1166-1175. [CrossRef]

55. Girardin, F.; Fiore, F.D.; Ratti, C.; Blat, J. Leveraging explicitly disclosed location information to understand tourist dynamics: A case study. J. Locat. Based Serv. 2008, 2, 41-56. [CrossRef]

56. Kádár, B. Measuring tourist activities in cities using geotagged photography. Tour. Geogr. 2014, 16, 88-104. [CrossRef]

57. García-Palomares, J.C.; Gutiérrez, J.; Mínguez, C. Identification of tourist hot spots based on social networks: A comparative analysis of European metropolises using photo-sharing services and GIS. Appl. Geogr. 2015, 63, 408-417. [CrossRef]

58. Instituto Nacional de Estatística. Censos 2011 Resultados Definitivos-Região Lisboa; Instituto Nacional de Estatística: Lisboa, Portugal, 2012; ISBN 978-989-25-0185-7.

59. Entidade Regional de Turismo da Região de LIsboa (ERT-RL). Plano Estratégico para o Turismo na Região de Lisboa 2015-2019. Available online: http:/ / www.ertlisboa.pt/fotos/editor2/lis_9970_04248_007_15.pdf (accessed on 11 December 2017).

60. Instituto Nacional de Estatística. Estatísticas do Turismo 2016; Instituto Nacional de Estatística: Lisboa, Portugal, 2017; ISBN 978-989-25-0396-7.

61. Instituto Nacional de Estatística. Estatísticas do Turismo 2014; Instituto Nacional de Estatística: Lisboa, Portugal, 2015; ISBN 978-989-25-0308-0.

62. Observatório de Turismo de Lisboa. Survey to the Purpose of Trip in Lisbon City 2014. Available online: https:/ / www.visitlisboa.com/sites/default/files /2016-10/Survey\%20on\%20the\%20Purpose\% 20of\%20Trip\%202014\%20-\%20Lisbon\%20City.pdf (accessed on 11 December 2017).

63. Observatório Turismo de Lisboa. Visitors Activities and Information Survey in Lisbon Region 2015. Available online: https:/ / www.visitlisboa.com/sites/default/ files/2016-10/VISITOR\%20ACTIVITIES\%20AND\% 20INFORMATION\%20SURVEY\%202015.pdf (accessed on 11 December 2017).

64. Anselin, L. Local Indicators of Spatial Association-LISA. Geogr. Anal. 1995, 27, 93-115. [CrossRef]

65. Berry, W.; Feldman, S. Multiple Regression in Practice; Sage: Thousand Oaks, CA, USA, 1985.

66. Hair, J.F. Multivariate Data Analysis with Readings; Prentice Hall: Upper Saddle River, NY, USA, 1995.

67. Ringle, C.; Wende, S.; Becker, J.-M. SmartPLS 3. Available online: https:/ / www.smartpls.com/ (accessed on 11 December 2017).

68. Salvati, L.; Gargiulo Morelli, V.; Weijnen, M.; van Bueren, E.; Wenzler, I.; De Reuver, M. Towards Intelligently—Sustainable Cities? Tema. J. Land Use Mobil. Environ. 2013, 6, 73-86.

69. Andrejevic, M.; Burdon, M. Defining the Sensor Society. Telev. New Media 2014, 16, 19-36. [CrossRef]

70. Del Chiappa, G.; Baggio, R. Knowledge transfer in smart tourism destinations: Analyzing the effects of a network structure. J. Destin. Mark. Manag. 2015, 4, 145-150. [CrossRef]

71. Chen, L.; Ng, E.; Huang, S.-C.; Fang, W.-T. A Self-Evaluation System of Quality Planning for Tourist Attractions in Taiwan: An Integrated AHP-Delphi Approach from Career Professionals. Sustainability 2017, 9, 1751. [CrossRef]

72. Paul, P. Tallon Corporate Governance of Big Data: Perspectives on Value, Risk, and Cost. Computer 2013, 46, 32-38. [CrossRef]

73. Minghetti, V.; Buhalis, D. Digital Divide in Tourism. J. Travel Res. 2009, 49, 267-281. [CrossRef]

74. Tachizawa, E.M.; Alvarez-Gil, M.J.; Montes-Sancho, M.J. How "smart cities" will change supply chain management. Supply Chain Manag. Int. J. 2015, 20, 237-248. [CrossRef] 
75. Saravanan, S.; Sadhu Ramakrishnan, B. Preserving privacy in the context of location based services through location hider in mobile-tourism. Inf. Technol. Tour. 2016, 16, 229-248. [CrossRef]

76. Bruns, K.; Jacob, F. Value-in-Use and Mobile Technologies. Bus. Inf. Syst. Eng. 2014, 6, 349-359. [CrossRef]

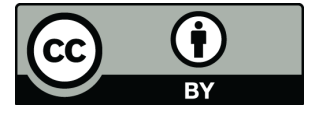

(C) 2017 by the authors. Licensee MDPI, Basel, Switzerland. This article is an open access article distributed under the terms and conditions of the Creative Commons Attribution (CC BY) license (http://creativecommons.org/licenses/by/4.0/). 